\title{
ЗДОРОВ'Я ЯК СИСТЕМНЕ ПОНЯТТЯ: КРИТЕРІЇ ПСИХОЛОГІЧНОГО ЗДОРОВ'Я
}

\section{Работа Тетяна Олександрівна}

Науковий кореспондент Інституту психології імені Г.С. Костюка НАПН Украӥни лабораторії психології навчання ім. І.О. Синиці, м. Київ, (Украӥна)

\begin{abstract}
Анотація. У даній роботі розглянуто питання здоров'я як системного поняття, а також висвітлено критерії психологічного здоров'я. Акцентовано увагу на впливі культури, виховання та ЗМІ на сприйняття та відношення до індивідуального психологічного здоров'я $i$ здоров'я загалом. Висвітлено фактори, щзо формують здоров'я людини. Зазначено, щзо збереження здоров'я та повноцінного життя громадян $є$ однією із найважливіших изілей світової спільноти, відображених у засадах європейської політики «Здоров'я-2020: основи Європейської політики в підтримку дій держави $i$ суспільства в інтересах здоров'я $i$ благополуччя». Висвітлено три рівні опису цінності «здоров'я». Акцентовано увагу на тому, щзо y міру росту добробуту населення, задоволення його природних первинних потреб, відносна иінність здоров'я усе більше буде зростати. Зазначено, щзо психологічний рівень здоров'я обумовлений психічними особливостями людини, можливостями забезпечити $i$ подолати хворобу, способом життя і розумінням того, щчо здоров'я - цее не тільки стан організму, але $i$ стратегія життя.
\end{abstract}

Ключові слова: здоров'я, система, психіка, населення, профілактика.

Постановка проблеми. Двадцять перше століття характеризується зростанням i зміною характеру навантажень на організм людини у зв'язку з ускладненням суспільного життя, збільшенням ризиків техногенного, екологічного, психологічного, політичного i військового характеру, що провокують негативні зрушення у стані здоров'я. В даний час в нашій країні чимало політиків і політологів, канали ЗМІ змагаються в тому, щоб намалю- вати похмуру картину завтрашнього дня, перемогти конкурентів в цьому недоречному змаганні із залякування населення. Результатом цього є різноманітні негативні наслідки, в тому числі і в аспекті душевного здоров'я. Людині потрібні не тільки вірні уявлення про життя, але ще і віра в те, що життя може бути іншим.

Стан здоров'я громадян безпосередньо зумовлює рівень продуктивності праці в сус- 
пільстві, значною мірою впливає на перспективи їі соціально-економічного розвитку. Як зазначають провідні фахівці Всесвітньої організації охорони здоров'я, тільки суспільство, що складається із фізично і духовно здорових індивідів із значною тривалістю активного життя, спроможне досягти сталого прогресу в усіх сферах своєї життєдіяльності.

Аналіз останніх досліджень i публікацій. Проблеми розвитку системи охорони здоров'я розглядали у своїх працях В. Куценко, Д. Полозенко, І. Чупрунов. Психологічне дослідження здоров'я особистості проводилось Л. Виготським, О. Леонтьєвим, С. Рубінштейном, П. Гальперіним. Сильний вплив на становлення системної теорії справила наукова спадщина академіка В. Бехтерєва i його послідовників: А. Лазурського, М. Басова, В. Мясищева, Б. Ананьєва і ін. У жодній іншій психологічній школі ідея цілісного, комплексного розгляду людини не була настільки яскраво і переконливо реалізована в методологічному і експериментальному планах. Заслуга звернення до системності на сучасному етапі психології належить Б. Ломову.

Метою даної роботи $є$ теоретичний аналіз здоров'я як системного поняття та висвітлення критеріїв психічного здоров'я зокрема.

Виклад основного матеріалу. Здоров'я людини - це її головне надбання. Здоров'я це не тільки повноцінно функціонуючий організм, але і душевна гармонія. Саме про це йде- ться в трактуванні поняття «здоров'я», що знаходиться в преамбулі Статуту Всесвітньої Організації Охорони Здоров'я (ВОО3): «Здоров’я - це стан повного фізичного, душевного і соціального благополуччя, а не тільки відсутність хвороби або фізичних дефектів» [9].

Здоров'я людини є складним поняттям, що складається з декількох компонентів:

1. Соматичне здоров'я;

2. Фізичне здоров'я;

3. Професійне здоров'я;

4. Сексуальне здоров'я;

5. Репродуктивне здоров'я;

6. Моральне здоров'я;

7. Психічне здоров'я.

Здоров'я визначає процес адаптації індивіда до соціально створеної реальності, до змін зовнішнього середовища.

До факторів, що формують здоров'я людини відносяться наступні:

$50 \%$ - спосіб життя визначається соціально-економічними умовами життя. Сюди входить режим праці і відпочинку, культурний рівень, харчування, особиста гігієна, заняття фізичною культурою і спорTOM.

$20 \%$ - фактори зовнішнього середовища (природно-кліматичні умови).

$20 \%$ - біологічні чинники (генетична схильність здоров'я і хвороби).

$10 \%$ - стан медичної допомоги в країні $[10$, c. 18$]$. 
Держава розглядає здоров'я населення однією $з$ найбільших цінностей, яке є необхідним компонентом розвитку та соціальноекономічного процвітання України. Саме тому створення оптимальних умов для реалізації потенціалу кожного громадянина впродовж всього життя та досягнення адекватних стандартів якості життя та благополуччя населення є одним із основних завдань Стратегії сталого розвитку. Збереження здоров'я та повноцінного життя громадян $є$ однією із найважливіших цілей світової спільноти, відображених у засадах європейської політики «Здоров'я2020: основи Свропейської політики в підтримку дій держави і суспільства в інтересах здоров'я і благополуччя» [7, с. 3].

Здоров'я індивіда $є$ динамічним станом, процесом збереження і розвитку його біологічних, фізіологічних і психічних функцій, оптимальної працездатності і соціальної активності при максимальній тривалості життя.

Узагальнюючи думки фахівців щодо феномену здоров'я, можна сформулювати ряд аксіоматичних по своїй суті положень:

1. В абсолютному значенні здоров'я не існує. Абсолютне здоров'я - ідеал.

2. Кожна людина здорова умовно. Жодна людина не буває протягом усього життя цілком здоровою.

3. Кожна людина може бути здоровою у певних умовах (клімат, їжа, праця). Є відповідні (нормальні) і невідповідні (шкідливі) життєві умови для конкретної людини. Умови, які є нормальними для однієї людини, можуть бути ненормальними для іншої [11, с. 45].

Системний підхід - $є$ тією єдиною методологічною основою, на якій тільки й може бути розглянута природа психічного у тій безлічі внутрішніх і зовнішніх відносин, в яких вона існує як цілісна система.

Однією з найсильніших сторін концепцій системного підходу, запропонованої Б. Ломовим, є його спроба виділити і розкрити зміст тих обов'язкових принципів, яких слід дотримуватися спеціаліста-психолога, якщо він не на словах, а на ділі хоче підійти до вивчення психічного як цілісної системи $[5$, с. 62]. Один $з$ найбільш важливих серед них принцип ієрархічності. Відповідно до нього людина постає як складна жива система, життєдіяльність якої забезпечується на різних, але взаємопов'язаних між собою рівнях функціонування. У найзагальнішому наближенні можна виділити три досить специфічних рівня розгляду: біологічний, психологічний і соціальний. Саме так ще в 1916 р. В. Мясищев визначив свою дослідницьку позицію у вивченні особистості, трактуючи іï як біо-психосоціальну єдність [8, с. 56].

Існують різні рівні вивчення людини: біологічний рівень (природа людини), рівень психологічний, на якому вона виступає як суб'єкт духовної діяльності, i, нарешті, рівень соціальний, на якому вона проявляє себе як особистість, що реалізує об'єктивні суспільні відносини, суспільно-історичний процес. 
I на кожному з названих рівнів здоров'я людини має певні особливості свого прояву.

Так, на біологічному рівні сутність здоров'я визначається як динамічна рівновага всіх внутрішніх органів і їх адекватне реагування на вплив навколишнього середовища [2, с. 108]. Відповідно порушення рівноваги, неадекватна реакція організму на фактори навколишнього середовища являють собою не що інше, як хвороба.

Якщо питання профілактики здоров'я, зміцнення захисних сил організму і лікування хвороб, з давніх пір знаходяться у полі зору традиційної медицини, то сучасні уявлення про сутність і шляхи забезпечення здоров'я, пов'язаного з психологічним рівнем, поки ще далекі від бажаної ясності і в цілому не можуть бути визнані задовільними.

Питання здоров'я, що відносяться до цього рівня, так чи інакше пов'язані з особистісним контекстом розгляду, в рамках якого людина постає як психічне ціле. Відповіді, вірно знайдені на них, врешті-решт допоможуть нам зрозуміти головне: що таке здорова особистість, як формується особистість людини в ранньому дитинстві, які визначені стадії проходить у процесі свого розвитку. Найбільшу стійкість, надійність риси сформованої особистості набувають в період зрілості [1, c. 115]. Потім, у старості, структура особистості піддається ряду змін в низхідному напрямку. В цілому ж особистість на всьому протязі життя може піддаватися тимчасовим або стійким змінам різного роду при захворюваннях, в тому числі і психічних. Чим гармонійніше з'єднані всі істотні властивості, складові особистості, тим більш вона стійка, урівноважена i здатна протидіяти впливам, які прагнуть порушити іiї цілісність.

До основних критеріїв психічного (психологічного) здоров'я можна віднести такі як адекватне сприйняття навколишнього середовища, свідоме здійснення вчинків, активність, працездатність, цілеспрямованість, здатність встановлювати близькі контакти, повноцінне сімейне життя, почуття прихильності і відповідальності по відношенню до близьких людей, здатність складати та здійснювати свій життєвий план, орієнтація на саморозвиток, цілісність особистості [3, с. 76]. Також, психічне здоров'я характеризується високим рівнем особистісного розвитку, розумінням себе і інших, уявленням мети і сенсу життя, здатністю керувати своїм життям (особистісна саморегуляція), умінням правильно (адекватно) відноситися до інших людей, до себе, усвідомленням відповідальності за своє життя і свій розвиток.

Перехід від психологічного до соціального рівня досить умовний. Психологічні властивості особистості, зазначає Б. Ломов, просто не існують поза системою суспільних відносин, в яку ця особистість включена [6, c. 214].

Інакше кажучи, людина постає на цьо- 
му рівні перш за все як істота суспільна і, відповідно, тут на передній план виходять питання впливу соціуму на здоров'я особистості. Відомо, що на психічне здоров'я впливають різні соціальні зв'язки, в тому числі сім'я, спілкування $з$ друзями і родичами, робота, дозвілля, приналежності до релігійних та інших організацій. Причому наслідки цих впливів можуть носити як благотворний, так i негативний характер [4, с. 35]. Тільки люди зі здоровою психікою зазвичай відчувають себе активними учасниками в соціальній системі, а саме душевне здоров'я прийнято визначати як залученість у спілкування, в соціальну взаємодію. Занедбаність виховання і несприятливі умови навколишнього середовища стають причиною різних форм неадекватної поведінки людини в суспільстві, кримінального розвитку особистості, іншими словами, причиною зниження іiї соціального здоров'я і надійності.

Висновки. Отже, на сьогоднішній день існує чимало факторів, які можуть негативно впливати на наш психологічний стан та організм в цілому. Але навички саморегуляції, вміння орієнтуватися на позитивну взаємодію з соціумом та саморозвиток надають певні перспективи у збереженні гармонійного стану особистості.

\section{Перспективою подальших дослі-} джень даної проблеми є детальніше дослідження актуального етапу індивідуальної категоризації поняття «психологічне здоров'я».

\section{Перелік використаних джерел:}

1. Дубровина И. В. Психическое здоровье детей и подростков в контексте психологической службы / И.В. Дубровина. - Екатеринбург, 4-е изд. - 2000. - 107 с.

2. Завгородня O. В. Проблема психологічного здоров'я: спроба теоретичного аналізу / О.В. Завгородня // Практична психологія та соціальна робота. - 2007. - № 1 (94). - C. 55-60.

3. Колотій Н.М. Психологічне здоров'я підлітків та його оцінка в умовах загальноосвітнього навчального закладу: автореф.дис....к.п.н.: 19.00.07 / Н.М. Колотій. - Х.: ХНУ, 2003. - 21 c.

4. Коновальчук В. До проблеми психологічного здоров'я як базової цінності особистості (глибинно психологічний аспект) / В. Коновальчук // Молодь і ринок. 2008. - № 3. - С. 61-65.

5. Куцеенко В. Потенціал охорони здоров'я / В. Куценко, Л. Богун // Економіка України. - 1999. - № 3. - С. 61-69.

6. Медична психологія: Підручник С.Д. Максименко, Я.В. Цехмістер, І.А. Коваль, К.С. Максименко; за заг. ред. С.Д. Максименко. - 2-ге видання. - К.: Видавничий дім «Слово», 2014. - 520 с.

7. Проект Концепції розвитку системи громадського здоров’я в Україні. - 2016. - 19 с.

8. Психология здоровья: Учебник для вузов / Под ред. Г.С. Никифорова. - СПб. Питер, 2006. - 607 с.

9. Устав (Конституция) Всемирной организации здравоохранения. - Женева, 1998.

10. Шувалов $A$. B. Гуманитарно-антропологические основы теории психологического здоровья / А.В. Шувалов // Вопросы психологии. - 2004. - № 66. - С. 1833.

11. Щербакова I. М. Духовний вимір психологічного здоров'я особистості в сучасному глобалізованому просторі / I.М. Щербакова // проблеми сучасної психології. - 2010. - 10. - С. 892-901.

\section{References (Transliteration):}


1. Dubrovina I.V. Psihicheskoe zdorov'e detej i podrostkov v kontekste psihologicheskoj sluzhby / I.V. Dubrovina. Ekaterinburg, 4-e izd. - 2000. - 107 s.

2. Zavgorodnja O. V. Problema psihologichnogo zdorov'ja: sproba teoretichnogo analizu / O.V. Zavgorodnja // Praktichna psihologija ta social'na robota. - 2007. - № 1 (94). - S. 55-60.

3. Kolotij N. M. Psihologichne zdorov'ja pidlitkiv ta jogo ocinka v umovah zagal'noosvitn'ogo navchal'nogo zakladu: avtoref.dis....k.p.n.: 19.00.07 / N.M. Kolotij. - H.: HNU, 2003. $-21 \mathrm{~s}$.

4. Konoval'chuk $V$. Do problemi psihologichnogo zdorov'ja jak bazovoï cinnosti osobistosti (glibinno psihologichnij aspekt) / V. Konoval'chuk // Molod' i rinok. - 2008. - № 3. - S. 61-65.

5. Kucenko V. Potencial ohoroni zdorov'ja / V. Kucenko, L. Bogun // Ekonomika Ukraïni. - 1999. - № 3. - S. 61-69.

6. Medichna psihologija: Pidruchnik S.D. Maksimenko, Ja.V. Cehmister, I.A. Koval', K.S. Maksimenko; za zag. red. S.D. Maksimenko. - 2-ge vidannja. - K.: Vidavnichij $\operatorname{dim} \ll$ Slovo», 2014. - $520 \mathrm{~s}$.

7. Proekt Koncepciï rozvitku sistemi gromads'kogo zdorov'ja v Ukraïni. - 2016. - 19 s.

8. Psihologija zdorov'ja: Uchebnik dlja vuzov / Pod red. G.S. Nikiforova. - SPb. Piter, 2006. - 607 s.

9. Ustav (Konstitucija) Vsemirnoj organizacii zdravoohranenija. - Zheneva, 1998.

10. Shuvalov A. V. Gumanitarno-antropologicheskie osnovy teorii psihologicheskogo zdorov'ja / A.V. Shuvalov // Voprosy psihologii. - 2004. - № 66. - S. 18-33.

11. Shherbakova I. M. Duhovnij vimir psihologichnogo zdorov'ja osobistosti $\mathrm{v}$ suchasnomu globalizovanomu prostori / I.M. Shherbakova // problemi suchasnoï psihologiï. - 2010. - 10. - S. 892-901.

\section{Rabota Tetyana}

Science Correspondent of G.S. Kostiuk Institute of Psychology of the National Academy of Educational Sciences of Ukraine, Laboratory of the Psychology of Studying named after I.O. Synytsya, Kyiv, (Ukraine)

\section{HEALTH SYSTEM AS A CONCEPT: CRITERIA OF MENTAL HEALTH}

\section{ABSTRACT}

The article is devoted considered as health system concepts and criteria highlighted mental health. The attention is focused on the impact of culture, education and media in the perception and attitude to individual mental health and health in general. The factors that form human health are noted. It is stressed that the maintaining health and normal life of citizens are the most important goals of the international community, these reflected in the principles of European policy Health-2020: Fundamentals of European Policy in Support of Actions of the State and Society in the Interests of Health and Well-Being». It is shown the factors that form the human health. The three levels are defined that describes the value of «health».

Much attention in the article is given to the importance of understanding of individual perception of the concept «mental health». The article gives information on further perspective of research, which is determining in the actual individual categorization of the concept «mental health».

Keywords: health system, psyche, population, prevention. 


\section{Работа Татьяна Александровна}

Научный корреспондент Института психологии имени Г.С. Костюка НАПН Украинь лаборатории психологии обучения им. И.А. Синицы, г. Киев (Украина)

\section{ЗДОРОВЬЕ КАК СИСТЕМНОЕ ПОНЯТИЯ: КРИТЕРИИ ПСИХОЛОГИЧЕСКОГО ЗДОРОВЬЯ}

Аннотация. В данной работе рассмотрены вопросы здоровья как системного понятия, а также освещены критерии психологического здоровья. Акцентировано внимание на влиянии культуры, воспитания, СМИ и окружающей среды на восприятие и отношение к индивидуальному психологическому здоровью и здоровью в целом. Отмечено, что сохранение здоровья и полноценной жизни граждан является одной из важнейших целей мирового сообщества, отраженных в основе европейской политики «Здоровье-2020: основы Европейской политики в поддержку действий государства и общества в интересах здоровья и благополучия». Освещены факторы, формирующие здоровье человека. Определены три уровня описания ценности здоровья. Акцентировано внимание на том, что по мере роста благосостояния населения, удовлетворения его естественных первичных потребностей, относительная ценность здоровья все больше будет возрастать.

Также, в статье рассмотрена важность понимания индивидуального восприятия понятия «психологическое здоровье». Представлены результаты научных исследований по проблеме общего представления о психологи- ческом здоровье. Также, определено, что психологическое здоровье является вариативным и индивидуально обусловленным. Определена дальнейшая перспектива исследования, которая заключается в определении актуальной индивидуальной категоризации понятия «психологическое здоровье».

Ключевые слова: здоровье, система, психика, население, профилактика.

Дата отримання статті: 27.04.2017 Дата рекомендації до друку: 02.05.2017 